\title{
The climatization of global politics: introduction to the special issue
}

\author{
Stefan C. Aykut ${ }^{1}$ D $\cdot$ Lucile Maertens $^{2}$
}

Accepted: 17 May 2021 / Published online: 26 July 2021

(C) The Author(s) 2021

\begin{abstract}
Climate change now constitutes a major issue in world politics, intersecting with and shaping many other political domains, and wider patterns of social and economic life. Global climate governance is also no longer restricted to multilateral negotiations under the UN Climate Convention: it increasingly extends beyond the international climate regime to climatize other areas of global politics. This concept of climatization points to a powerful but uneven process of extension, translation, and social coordination, as climate change becomes the frame of reference through which other policy issues and forms of global activism are mediated and hierarchized. This special issue brings together contributions on both theoretical aspects and empirical cases of the climatization process. The introduction sets out a conceptual framework to systematize these observations and guide further research. First, we identify the preconditions for, and driving forces behind, climatization. We then sketch the contours of an emergent 'climate logic' that reshapes affected domains, and examine the wider implications of climatization for global politics. Beyond the climate case, we hope this will provide new ways to observe and understand contemporary transformations of global society and global governance.
\end{abstract}

Keywords Global climate governance · Paris agreement · Climatization · Securitization

Stefan C. Aykut

stefan.aykut@uni-hamburg.de

1 Fellow at the Humanities Centre for Advanced Studies "Futures of Sustainability" Universität Hamburg, Hamburg, Germany

2 Faculty of Social and Political Sciences, Institute of Political Studies (IEP), University of Lausanne, Quartier UNIL-Mouline, Bâtiment Géopolis, Office 4550, 1015 Lausanne, Switzerland 


\section{Introduction}

Climate change now constitutes a major issue in world politics, intersecting with and shaping many other political domains, and profoundly affecting wider patterns of social and economic life (Dalby 2016; Vogler 2016). Consequently, global climate governance has become the focal point for a wide array of debates and conflicts around issues from development and global equity to energy policy, urban planning, security and migration. The annual conferences of the parties (COPs) held under the auspices of the United Nations climate convention (UNFCCC) are thus not only key moments in global climate politics, but also events of wider geopolitical significance. They attract ever more public attention and an increasingly diverse set of actors, while creating political momentum for climate-related issues beyond the climate arena (Kolleck et al. 2017). Climate governance actors and mechanisms thereby extend their sphere of influence by 'climatizing' other domains of global politics (Aykut et al. 2017).

The concept of climatization points to a powerful yet uneven social process in which climate change is increasingly becoming the frame of reference for the mediation and hierarchization of other global issues. This does not only, or even primarily, result from legal dispositions in climate treaties or formalized linkages between international organizations (van Asselt et al. 2005). Instead, it is often brought about by the work of a myriad of actors and organizations engaging in climate-related activism, building transnational networks, or refracting their issues and objects through a climate lens. These actors may enter the climate arena to lobby for the inclusion of their concerns in climate talks, or to gain access to the symbolic and economic capital associated with the climate regime. They may be driven to include climate concerns in their traditional mandate by political and normative convictions, or on pragmatic or strategic grounds. To encompass this wide array of situations and motives, we define climatization broadly as the process through which an issue, actor or institution is framed as related to anthropogenic climate change and relevant to climate politics. More specifically, this frequently leads to the extension of the jurisdiction of climate governance institutions, the inclusion of the climatized issues, actors or institutions in climate policy networks, and their treatment according to the dominant logics of the international climate regime. ${ }^{1}$

This special issue examines the process through which climate change is transforming global governance, as both an increasingly central issue on the international stage and an increasingly structured policy domain with its specific modes of governing, networks of actors, discourses, and knowledge practices. Collectively, the contributions aim to assess how and why climate change is becoming a dominant frame in international politics. In doing so, they also contribute to understanding the dynamics and drivers of climatization. Speaking to climate governance scholars and researchers in other areas of global politics, it addresses what, in our view, are two major blind spots in the literature. First, existing work on global climate governance

\footnotetext{
1 This can be conceptualized as a sectorial expansion or 'globalization' of the climate problem (Foyer et al. 2017: 5).
} 
has argued that a central objective of this governance since the adoption of the Paris Agreement in 2015 has been to 'facilitate' (Hale 2016) global climate action and 'orchestrate' (Abbott 2018) a wider 'polycentric' landscape of transnational governance initiatives (Jordan et al. 2018). However, this literature ultimately has little to say on exactly how, where, and why such functionalist desiderata of social coordination might actually manifest in practice. ${ }^{2}$ What social logics and mechanisms are involved? We believe that a focus on climatization as a social process can provide important insights here, by offering a perspective on decentralized coordination around the climate problem that complements functionalist accounts. Second, an important body of work has examined the political agenda-setting processes through which climate change became a politically relevant topic, and the framing contests in its construction as a (global) public problem (Hajer 1995; Trumbo 1996; Pettenger 2007). Scholars have assessed the role of wider political dynamics in the (de)politicization of climate change, and how broader discursive frames have shaped global climate governance (Bäckstrand and Lövbrand 2016). Building on this literature, the articles gathered in this special issue further explore these framing processes and their implications beyond climate politics as such. In other words, while previous work has mostly considered what politics is doing to climate change, this special issue examines what climate change is doing to (global) politics.

To do this, we believe that a wider focus is needed in terms of actors, arenas, and climate-related practices, as well as a more fine-grained understanding of the discursive and symbolic dimensions of global (climate) politics. We approach climate governance as a multi-actor, trans-scalar and nonlinear process of social coordinationenacted through diplomatic practices and performances (Schüssler et al. 2014), in networked relations between state and non-state actors (Bernstein et al. 2010; Betsill and Bulkeley 2004), and through global discourses with normalizing effects on the everyday (Bäckstrand and Lövbrand 2006; Paterson and Stripple 2010). This perspective foregrounds processes, practices, and discourses (rather than just regimes, international organizations, and legal rules). It examines the diversity of actors and scales involved (rather than just states and international negotiations). And it treats the boundaries of climate governance not as fixed, but as constantly negotiated and enacted by the actors involved. Combining perspectives rooted in international relations, international political sociology, political geography, political ethnography, and science and technology studies, the special issue seeks to contribute to building a stronger theoretical framework to study the extension of the climate realm and the resulting implications for global politics.

The articles in this issue make three main contributions to that project. First, they help to further characterize and specify the process of climatization. Focusing on a wide variety of actors, issue areas, and governance scales, they display the diversity of motivations and strategies that drive the climatization process, but also bring out

\footnotetext{
${ }^{2}$ Van Asselt and Zelli (2018: 36), for instance, note that 'whether and for how long the UNFCCC-the COP or the secretariat-has been an orchestrator is an open question', and go on to argue that while 'the international regime has exerted at least some influence' on transnational climate governance, it remains unclear 'how much' and 'through precisely what causal mechanisms' this may have happened.
} 
shared patterns and mechanisms. One set of papers investigates the role and modes of coordination of non-state actors, with a focus on the climate justice movement (de Moor 2020), transnational indigenous grassroots movements (Dupuits 2020), and philanthropic foundations (Morena 2020). These studies show how civil society actors enter the climate arena by establishing transnational networks, how they reformulate their political aims and interests by relating them to climate concerns, and how they attempt, with variable success, to shape climate governance debates. Looking at these actors and their mobilizations and framings also sheds further light on the origins of some of the main characteristics of the Paris climate regime. These characteristics are further spelled out in Aykut et al. (2020) analysis of post-Paris climate politics. The authors show that symbolic elements and communicative techniques are central features of the new governance approach. Estève (2020) Jayaram (2020) supplement this panoramic overview of actors and policy arenas by focusing, respectively, on the French and Indian armed forces. They identify the drivers and mechanisms pushing for the climatization of the military in both countries, while also pointing to the very selective ways in which military actors frame and address climate change. Finally, Maertens (2021) examines the confrontation of another important international organization, the UN Security Council, with the power of attraction of the climate topic, and characterizes the overlapping dynamics through which the Security Council is progressively being climatized.

Second, the articles reveal the ambiguities, frictions and resistances that accompany both the diffusion of climate change into other global arenas and the incorporation of new issues into climate governance. Dupuits (2020) shows that climatization can be reversed when the outcomes of climatizing strategies do not meet the expectations of their initiators. In this case, a transnational grassroots network-the Mesoamerican Alliance of Peoples and Forests-pulled out of climate negotiations when it became clear that they would not be able to advance their agenda on territorial security within the UNFCCC. De Moor (2020) highlights resistances to climatization, which occur when a climate framing tends to homogenize very different grievances, complicating activists' efforts to define an alternative 'globality'. Similarly, Maertens (2021) shows that the UN Security Council cannot escape climate discussions despite fierce resistance by some member states. Frictions also appear in Estève's (2020) account of framing contests over the links between climate change and insecurity, which involve strategies of climatization, securitization, and riskification. Jayaram (2020) shows that-partly as a result of such differences in strategies-climatization can come in different forms and degrees, often appearing as purely symbolic or strategic, and less often as precautionary or even transformative. This kind of focus on symbolic action and communicative strategies can also be found at the very heart of global climate governance, with its 'performative' approach to global climate action (Aykut et al. 2020). Taken together, the contributions provide new conceptual resources to capture the current remodelling of world politics by climate change, drawing out the implications of climatization as a dominant framing and highlighting forms of resistance to it.

Third, the papers link climatization processes to broader global trends and issues. On the one hand, they draw attention to the multiple ways in which different domains of global politics connect, interact, and influence each other. The three 
studies on the intersection between the fields of security and climate change, for example, demonstrate the need to go beyond an exclusive focus on the 'securitization' of climate change (McDonald 2013), using climatization as an alternative or complementary way of theorizing these interactions (Estève 2020, Jayaram 2020, Maertens 2021). On the other hand, the climatization lens also provides new ways to reflect on shifts in global power relations with the rise of soft (Abbott and Snidal 2000), private (Hall and Biersteker 2002), and hybrid (Andonova 2010; Graz 2006) forms of global governance. Morena (2020) shows that US philanthropic foundations played a key role in shaping the bottom-up, soft law approach of the Paris climate regime. Aykut et al. (2020) examine how the focus on private action and the importation of management tools into global governance changes how international agreements are implemented. Non-state actors are also central in de Moor's (2020) analysis of attempts by the climate justice movement to establish a global space of mobilization and conflict. More broadly, the articles seek to reflect on the central position of climate change in global politics without simply reproducing it. Instead, they shed new light on issues of power and domination resulting from unequal access to global arenas and governance scales. In doing so they contribute to a deeper understanding of current transformations not only of climate governance, but also of global politics more broadly.

In the light of the insights provided by the studies in this issue, we develop six theses: (1) Climatization is a process, not an end state; (2) Climatization is afforded by problem characteristics and rooted in past governance failures; (3) Climatization operates not only through strategic moves, but through a wide variety of practices; (4) Climatization is driven by motives of problem control, adaptation to change, and institutional expansion; (5) Domains affected by climatization reveal a climate logic in the making; (6) Climatization reveals, reproduces, and rearticulates power relations. In the conclusion, we advocate for further research on climatization and its interaction with other contemporary transformations of global governance.

\section{(1) Climatization is a process, not an end state}

Social science scholars have coined various terms which use the suffix '-ization' to draw attention to broad historical dynamics in which one social sphere becomes a dominant force of transformation in other spheres: 'judicialization' points to the increasing 'reliance on courts and judicial means for addressing core moral predicaments, public policy questions, and political controversies' (Hirschl 2008: 253); 'financialization' to the 'increasing role of financial motives, financial markets, financial actors and financial institutions in the operation of the domestic and international economies' (Epstein 2005: 3); and 'medicalization' to the numerous 'processes through which more and more social issues become framed as medical problems and are responded to through medical frameworks' (Elbe 2010: 15).

Conceiving climatization in such processual terms presents two decisive advantages over other notions, such as 'climate mainstreaming' or 'greenwashing'. First, the analytical focus is immediately placed on ongoing changes. The articles in this special issue take an interest in the perpetual renegotiations of the boundaries of the climate realm. Instead of assuming a fixed delimitation of climate politics, they empirically assess its expansion (and sometimes its shrinkage) in specific contexts. This echoes debates among securitization scholars, where the Copenhagen School's 
fixed definition limiting the domain of 'security' to exceptional measures has been challenged (Trombetta 2008: 591). By analogy with this literature, we see climatization as unfolding through climatizing moves, understood as attempts to impose a climate frame on another object or issue and/or subject it to climate governance practices. Climatization, in this sense, is 'an always (situated and iterative) process of generating meaning' (Stritzel 2007: 366), which simultaneously affects both the climatized object and the climate problem itself. A focus on climatization hence helps us to recognize unstable (and even reversible) developments. Climatization in this sense is not an end state reached through past changes, but an ongoing process of transformation.

Second, the concept of climatization does not specify the form and intensity of such shifts, or the motivations behind them. It is broad enough to encompass superficial and largely symbolic changes as well as much deeper transformations. It neither presupposes specific intentions, like the concept of greenwashing, nor does it limit the focus to the strategic dissemination of policy frames, like the concept of climate mainstreaming (Methmann 2010). It covers observable transformations in both discourses and practices. Furthermore, we do not assume that climatization is in itself essentially good or bad. This contrasts with strands in securitization studies where scholars express normative concerns vis-à-vis securitizing moves. These authors draw attention to the risks of militarization, the reliance on undemocratic decisionmaking procedures, the (potentially unintended) consequences in terms of discrimination, and more broadly 'the signifying work' of the word 'security' (Huysmans 1998: 226). In her study of the securitization of the environment, Floyd challenges the normative assumptions underlying such warnings, suggesting that 'not all securitisations are morally equal' (Floyd 2010: 56). Likewise, our starting point in this special issue is that climatizing moves may respond to very different normative considerations, and that their effects should be assessed empirically, without presuming specific outcomes, positive or negative. Such normative (and analytical) openness, we believe, is needed to ensure the heuristic value of the concept of climatization and its ability to shed light on contemporary transformations in global politics.

(2) Climatization is afforded by problem characteristics and rooted in past governance failures

If climatization is a process, then what are its origins? Are there features of the climate problem that predispose it to expand, or explain its force of attraction? We believe that the answer to these questions lies in how climate change has been constructed as a scientific object and as a public problem. Climatization draws on, or is afforded by, scientific notions of the interconnectedness of the climate system and the transversal nature of the climate problem. To understand the climate, scientists need to take into account a potentially infinite set of other elements and processes, from water and carbon cycles to oceanic currents, ocean-atmosphere interactions, and ecosystem dynamics (Edwards 2010). Climate policy, too, is complex in its thematic scope, linking up to other policy domains and societal spheres. To really fight climate change and adapt to a warming climate, we may have to transform quite literally 'everything' (Klein 2014), from everyday habits and mobility practices to energy systems and management routines, as well as the regulation of global energy markets, trade, and finance. In other words, core 
features of the climate problem and its social construction mean that its manifestations are ubiquitous across world society (Aykut 2020).

The climatization process is also rooted in past governance failures, which have exacerbated the urgency and increased the magnitude of the necessary changes. Past governance decisions did not prevent, halt, or even slow dangerous global warming. As a result, more and more aspects of global society are affected by the consequences, and decarbonization scenarios imply ever more drastic changes in global economic and social practices (Ripple et al. 2019). The contributions to this special issue show that climate change has direct effects on everyday practices and administrative routines in multiple domains (Estève 2020; Jayaram 2020; Maertens 2021), while affecting social movements and mobilizations (de Moor 2020; Dupuits 2020). Mainstreaming climate concerns in all sectors therefore increasingly appears as the only viable strategy to avoid major disruptions after more than 30 years of international negotiations with utterly insufficient outcomes (Moncel and van Asselt 2012; Hale 2016). And yet climatization is no panacea: it may well reproduce the same institutional mechanisms that have thus far failed to prevent dangerous climate change.

\section{(3) Climatization operates not only through strategic moves, but through a wide variety of practices}

The contributions to this special issue show that climatization is not necessarily intentional or strategic. It unfolds through a large variety of practices, understood here as socially meaningful patterns of action (Adler and Pouliot 2011). Each of the articles relies on different methodological tools to trace and analyse these practices, which range from everyday social routines to forms of administrative action and policy-making. As such, many of these practices are not climatespecific. Agenda-setting, lobbying, and the production of expertise, to name just a few, are a common feature across political domains. But taken together, the articles display a set of concrete ways in which actors turn a climate lens on an issue (Dupuits 2020; Maertens 2021), extend the realm of climate politics (Aykut et al. 2020; de Moor 2020), and integrate climate change considerations into other policy domains (Estève 2020; Jayaram 2020). Below, we distil a list of climatization practices from the different case studies (Table 1). We group them into categories: framing and communication; policymaking and governance; networking and mobilization; documenting and research; and financing and implementation. This list may, we hope, be expanded and refined by future research. By surveying the different ways in which climatization occurs empirically, it shows that to understand what climate change is 'doing to' (global) politics, we should pay close attention to such everyday practices and routines. It also stresses that despite the magnitude and urgency of the climate emergency, the transformation of global politics is not necessarily sudden or disruptive. Climatization also foregrounds various more incremental changes that, in combination, may deeply and durably transform the governance of global problems. Practice tracing methods (Pouliot 2014) and other qualitative research strategies, including participant observation and ethnographic methods (Campbell et al. 2014), are often needed to uncover the concrete ways in which climatization unfolds and affects global governance. 
Table 1 Climatization Practices

\begin{tabular}{|c|c|}
\hline \multirow[t]{5}{*}{ Framing and Communication } & Campaigning with climate arguments \\
\hline & Climate-related reporting and storytelling \\
\hline & Establishing responsibility in the climate crisis \\
\hline & Linking climate change with other issues \\
\hline & Climate-centred agenda-setting \\
\hline \multirow[t]{4}{*}{ Policymaking and Governance } & Adopting climate policy measures \\
\hline & Building climate task forces and organizations \\
\hline & Climate-related lobbying \\
\hline & Negotiating climate governance goals and treaties \\
\hline \multirow[t]{5}{*}{ Networking and Mobilization } & Advocating for technical solutions \\
\hline & Demonstrating for climate action \\
\hline & Engaging in direct action against polluters or infrastructures \\
\hline & Including climate actors in other policy arenas \\
\hline & Sustaining climate networks and initiatives \\
\hline \multirow[t]{5}{*}{ Documenting and Research } & Carbon disclosure and reporting \\
\hline & Circulating and publicizing climate expertise \\
\hline & Climate-related forecasting \\
\hline & Creating metrics and standards to monitor climate action \\
\hline & Producing climate risk analyses \\
\hline \multirow[t]{5}{*}{ Financing and Implementation } & Climate proofing \\
\hline & Disaster intervention \\
\hline & Funding climate advocacy networks and think tanks \\
\hline & Setting up and supporting adaptation/mitigation projects \\
\hline & Strategic planning in public and private organizations \\
\hline
\end{tabular}

(4) Climatization is driven by motives of problem control, adaptation to change, and institutional expansion

The practices listed above respond to three broad motives. While these may often overlap in concrete empirical cases, distinguishing them helps to identify the main driving forces behind climatization. A motive of problem control underlies attempts to (re)define the problem and mitigate it by designing appropriate policy responses. It drives practices of agenda-setting in international organizations (Maertens 2021). It supports the negotiation and formulation of climate policy objectives, the mainstreaming of such objectives across governance arenas and levels, their translation into policy instruments, and their implementation in administrations and businesses. Post-Paris climate governance actively supports climatization in this sense through its polycentric and facilitative approach, which relies on communicative tools to spread climate concerns among private and public actors (Aykut et al. 2020). A motive of problem control also drives networking and agenda-setting activities by philanthropies and NGOs aimed at promoting new approaches in global climate governance (Morena 2020), as well as practices of issue-linking and campaigning by social movements striving to advance alternative problem frames (de Moor 2020). 
A motive of adaptation to change is found in responses and strategies used to cope with and react to a changing environment. This can be seen, for example, in practices that local communities and administrations use in building adaptive capacities to respond to a warming climate, and in businesses' reactions to changes in market environments brought by climate policy interventions. The climate problem is increasingly becoming an inescapable reality for indigenous peoples who are directly affected by adaptation policies aiming either to restore strict conservation policies or to establish market-based conservation mechanisms (Dupuits 2020). This is also true for non-climate oriented international organizations, which are required to address climate change in their policy and programming (Hall 2015; Maertens 2021), and military organizations which are directed to integrate warming impacts into their strategic planning (Estève 2020; Jayaram 2020). In these cases, climatization is motivated by self-preservation in the face of warming impacts, or resistance to climate-related transformations and policies, and aims at building long-term resilience or ensuring institutional and organizational continuity in a changing world.

Finally, a motive of institutional expansion structures endeavours to use the climate topic to increase an organization's public profile, attract political or media attention, or tap into climate-related funding opportunities. Institutional expansion is widespread in global governance, where international bureaucracies commonly show 'mission creep' by engaging in 'a significant amount of activities into new policy areas' (Littoz-Monnet 2017: 584). In the case of climate change, this can be seen in international organizations (Maertens 2021), among non-state actors (de Moor 2020; Dupuits 2020; Morena 2020), and among professionals in a specific policy domain such as military affairs (Estève 2020; Jayaram 2020). This drive towards institutional expansion motivates practices aimed at benefiting from the symbolic and material capital conferred by UN climate summits and climate-related activities (e.g. adaptation programs delivered by IOs, advocacy work by NGOs, media attention, etc.), including attempts to refract issues through a climate lens in order to enter climate arenas. As climate change moves up the international agenda, it has come to exert an increasing force of attraction for actors seeking to attract funds, gain recognition, or reap other benefits (Dupuits 2020; Jayaram 2020; Maertens 2021). In return, by expanding their field of action to cover climate change, these actors drive climatization processes, potentially through alternative framing strategies-such as riskification and securitization (Estève 2020).

\section{(5) Domains affected by climatization exhibit a climate logic in the making}

Domains, issues, and objects affected by climatization often come to exhibit a set of common features as climate frames, experts, or policy instruments become dominant. As in the cases of securitization and judicialization, the homogenizing force of climatization processes can be described as a 'climate logic' imposed upon the climatized domain. The concept of a 'logic' refers to situations where 'actors, institutions or an entire policy field rely upon a specific way of reasoning, functioning and ordering things' (Louis and Maertens 2021: 14). But as the transformation of climate change into a distinct policy domain is a recent one, the study of climate logic is more exploratory than in the abovementioned cases. The practices, actors, and institutions that compose the field of climate politics are still comparatively heterogeneous, than, for instance, in the security field. We thus focus on drawing the 
Table 2 A climate logic in the making

\begin{tabular}{ll}
\hline Characteristic & Continuum \\
\hline Scientized & View from nowhere $\Leftrightarrow$ Plural ways of knowing \\
Planetary perspective & Global gaze $\Leftrightarrow$ Alternative globalities \\
Long-term temporality & Strategic planning $\Leftrightarrow$ Participatory futuring \\
Solution-oriented & Carbon reductionism $\Leftrightarrow$ Social transformations \\
\hline
\end{tabular}

contours of a climate logic in the making. Building on the contributions to this issue and on previous work, ${ }^{3}$ we identify a set of four features that characterize the emergent 'climate logic'. To reflect its emergent and unstable nature, we also identify observable and plausible variations within each of these characteristics. These are presented in the form of continua (see Table 2). We hope that future work will build on, further specify, and possibly extend these features, and track the progressive stabilization of the emerging climate logic along each of these continua.

First, climate logic is scientized. Climatization leads to an emphasis on scientific tools and framings, and tends to foreground expert discourses. Climate debates heavily draw on results obtained through numerical modelling, from general circulation models that estimate warming impacts to integrated assessment models that simulate future scenarios and evaluate mitigation strategies (Edwards 2010). Highly complex modelling tools have thereby become an obligatory passage point when introducing new issues or forms of expertise into global climate governance (Dahan 2010). As a result, climate discourses frequently adopt a 'view from nowhere' (Borie et al. 2021) that depoliticizes climate conflicts, for example when risk management tools are applied to assess the likelihood of political and social unrest in climate hotspots (Estève 2020; Maertens 2021). However, we also find instances where the introduction of new actors into climate arenas leads to a pluralization of ways of knowing, as when indigenous peoples emphasize the necessity of considering local and traditional knowledge in mitigation and adaptation strategies (Dupuits 2020).

Second, climate logic takes a planetary perspective. Climatization favours a radically global point of view on natural and social phenomena and their interactions. This 'global gaze' (Litfin 1999; Fogel 2004) rests on the observation that the climate system is inextricably interconnected at a planetary scale. With this interconnectedness comes a need for political cooperation: because carbon dioxide emissions do not stop at national borders, the climate issue is said to require a multilateral response. Actors in climatized domains therefore have to formulate their issues in planetary terms and connect them to Earth system processes. In doing so they

\footnotetext{
3 See, for instance, previous studies on the climatization of security practices (Oels 2012) and soil sciences (Kon Kam King et al. 2018). Closer to our categorization, Methmann (2010) identifies four discursive pillars of what he terms the 'global governmentality of climate protection': globalism, scientism, an ethics of growth, and efficiency. While we broadly agree on the first two characteristics, we depart from this framework on the latter two, by subsuming growth and efficiency under a new category (solutionoriented) and by adding a temporal dimension.
} 
must adopt a paradoxical understanding of universality: in the face of the climate challenge, we are all in the same boat, even as some regions and populations are much more affected than others. While climate logic always involves a global reference point, such a planetary perspective falls on a continuum between the top-down approaches of global governance and Earth system management (Aykut et al. 2020), and the construction of alternative globalities in social movements and transnational actor networks (de Moor 2020; Dupuits 2020).

Third, climate logic introduces a long-term temporality into public debates, policy processes and administrative routines. Climate research and climate debates build on different long-term temporalities, such as the century-long horizons of equilibrium change and slow feedback cycles in Earth system processes and the multidecadal perspectives of decarbonization scenarios that form the political horizons of global climate governance national low-carbon transformations (Aykut et al. 2020). Politically, climatization thus tends to favour a return of the plan, the scenario and the long-term strategy in public administration and governance. However, in some places the rise of climate concerns has also been instrumental to the rise of alternative 'techniques of futuring' based on participatory and deliberative methods (Hajer and Pelzer 2018).

Fourth, climate logic is solution-oriented. Climate governance debates frequently place value on market- and technical fixes over problem-centred or justice frames. Actors who wish to enter climate governance arenas therefore often feel compelled to foreground possible solutions and adopt a pragmatic, 'positive' discourse. The capacity to propose technical and managerial fixes, market-based instruments, or institutional reforms trumps calls for radical economic or political changes (Swyngedouw 2010). This is particularly salient in post-Paris climate governance, where the ritualized invocation of the 'Paris spirit' in high-profile meetings, the staging of best practices and corporate success stories, serve to sustain the positive narrative of an ongoing transition to a decarbonized world economy (Aykut et al. 2020; Morena 2020). The focus on solutions thereby favours a 'carbon reductionism' (Méndez 2020) that firmly protects the status quo of a profoundly unequal global political economy (Jayaram 2020; Maertens 2021; Morena 2020). More recently however, calls for climate justice and debates on deep decarbonization have been instrumental in foregrounding societal transformations that have the potential to challenge existing power structures (de Moor 2020; Jayaram 2020; Maertens 2021).

Importantly, arguing that the emergent climate logic varies along these four dimensions does not mean that the outcome of climatization processes is entirely open. We do discern some general tendencies within each of the dimensions. For example, while there are ongoing struggles around the recognition of plural ways of knowing in climate debates, model-based approaches and scientized framings are generally favoured (Foyer and Dumoulin 2017). While a planetary perspective can accommodate polycentric and bottom-up ways of organizing, it tends to invisibilize local contexts and struggles in debates on climate futures. And while climate logic is not necessarily 'post-political' per se (Swyngedouw and Wilson 2014), climatization frequently results in a focus on incremental solutions and techno-fixes that conform to a growth-oriented liberal world order. With regard to temporality, the picture is perhaps less clear, as the long-term perspective brought by climate concerns often 
contrasts with the short-term logics of contemporary capitalism and project-based governance (Boltanski and Chiapello 1999). It also sits uneasily with the urgency frequently invoked by activists and experts alike to characterize the climate crisis. Climate logic may therefore also foreground a different temporal register: a routinized invocation of urgency (Louis and Maertens 2021), in which it is always 'five minutes to midnight' (Geden 2018)... but never too late.

\section{(6) Climatization reveals, reproduces, and rearticulates power relations}

After this exploration of the motives and modes of climatization, we now look into the consequences of these transformations. We find that climatization reveals, reproduces, and rearticulates power relations. We know from other comparable cases of expanding and overlapping social spheres that these involve power struggles over the jurisdiction of social actors, logics, and practices of different fields. Hence, judicialization processes operate through an extension of the influence of judicial language and practice; securitization processes through the adoption of exceptional measures, the use of discourses of discrimination, and the extension of executive powers; and medicalization confers legitimacy upon health professionals and medical interventions into the medicalized field. Accordingly, the articles in this issue show that climatization tends to increase the sphere of influence of actors from the climate arena-climate scientists, climate policymakers, climate activists, (often self-proclaimed) climate victims, etc. At the same time, new actors enter climate arenas, and engage in struggles for recognition and influence. The question we pose here is therefore less about the effectiveness of climatization in terms of climate governance or carbon reductions, but rather about the ways in which climatizing moves unveil and affect global power dynamics. This means considering climatization not as a disincarnated dynamic, but as a social process in which actors advance their framings, build coalitions for specific solutions, or extend their sphere of action and legitimacy. Climatization thus becomes a useful lens to examine shifting power relations in global governance. The articles in this issue suggest three distinct ways to assess the outcomes and identify the winners and losers of climatization.

First, climatization reproduces and rearticulates power relations. Strategic climatizing moves can help powerful actors maintain their domination by incorporating and instrumentalizing climate change. U.S. philanthropic foundations mainstream their preferred political views (Morena 2020), armed forces expand their legitimacy to act on non-security issues including socio-ecological problems (Estève 2020; Jayaram 2020), and powerful states use climate change to demonstrate and consolidate their important role in multilateral fora (Maertens 2021). However, climatization also rearticulates power dynamics by expanding some actors' field of action and influence: not only climate experts, but also less powerful states and civil society. While grassroot movements seek to gain a legitimate voice during the COPs by climatizing their causes (Dupuits 2020), developing states that are vulnerable to warming impacts may use the political capital they acquire in the climate arena in other international venues. This is the case, for example, of St. Vincent and the Grenadines, the smallest state to secure a seat on the UN Security Council (Maertens 2021; see also the case of Bangladesh's 'weak power' in climate negotiations, Baillat 2018). 
Second, climatization shifts political responsibilities in time and in space. Climatization unfolds through the attribution and recognition of political responsibility not only in causing, but also in solving the climate crisis (Maertens 2021). It brings a long-term perspective to both discussions of historical responsibility and debates on present policymaking. This can produce frictions, as when the long-term objectives of global climate governance and their translation into net-zero pledges target 2050 instead of near-term action (Aykut et al. 2020). Climatization can also displace local and national responsibilities by focusing attention on the global level, and erase alternative, situated framings in the name of a common planetary problem (de Moor 2020). Inevitably, such dynamics depend on the actors driving the climatization process. They also reveal a broader underlying tension between the politicization of climate change, through climatizing moves, and its depoliticization, when responsibility is diluted among numerous actors-if everyone is responsible, no one is (Louis and Maertens 2021).

Third, climatization accommodates dynamics of inclusion and exclusion. It is enacted through and works to justify the involvement of new actors (scientists, consultants, etc.) and the deployment of new approaches (scientized, globalized, etc.). For instance, debates on the security implications of climate change have opened the doors of the UN Security Council to the UN Environment Programme, the World Meteorological Organization, and think tanks specialized in climate security (Maertens 2021). Attempts to reform global climate governance and extend its reach have invited a broader participation of non-state actors in international regulation (Aykut et al. 2020). Yet the recognition of such dynamics of inclusion should not obscure processes of exclusion, especially when the preference for a specific approach-science-based, market-oriented, etc.-marginalizes other understandings of the climate crisis (Dupuits 2020; de Moor 2020). Climatization may well challenge established hierarchies by setting new priorities (e.g. when the 'climate emergency' is framed as the most important global problem), disrupt established routines in many settings and organizations, and empower new actors and their issues and solutions. Nevertheless, in most cases the emerging climate logic does not unsettle existing power relations or the core objectives of hegemonic actors.

\section{Concluding remarks: climatization and the transformation of global governance}

Climate change increasingly appears as the paradigmatic environmental problem of our times, and as one of the most pressing crises affecting global society. It dominates international discussions on the protection of the environment and beyond, imposing new framings on other (global) problems. Through climatization, new subjectivities emerge in the everyday (Paterson and Stripple 2010) as much as in global politics (Death 2011). But, as in comparable processes of financialization and judicialization, different degrees or intensities of climatization can be observed. Climatization may be seen both in small incremental changes and in deeper societal transformations. Each of the case studies assembled in this special issue helps to 
delineate, characterize, and assess the contours of this social process and the extent of the changes it causes.

However, climatization is by no means the only macro-transformation affecting global society. It coincides or overlaps with, and is at times reinforced or moderated by, other social dynamics, which may in their turn reframe climate policy through the lens of another policy area or social sphere (e.g. by securitizing or financializing it). Further research is needed to obtain a more fine-grained understanding of such encounters, when two fields overlap or expand into each other's territory. Does one field and its logic typically dominate over the other? Under what conditions can we observe forms of hybridization wherein the framing, actors, and suggested policy action of separate policy domains merge? The outcome of climatizing moves is not always a clear power shift through the expansion of one domain over the other. Ongoing transformations can reinforce each other-as has been the case for the scientization of public policy, intensified through the rise of environmental issues (Beck 1986). Such evolutions might become more salient in the future, as climate policy instruments become increasingly financialized, or the management of climate impacts securitized. As more and more issues are framed as global problems deserving global action (Neveu and Surdez 2020), future research on the transformations of global governance should pay close attention to these processes, wherein actors compete to impose the logics of their respective domains on other domains. This also raises the question of the intermediaries of climatization, which we did not foreground here. What can be said about the actors that promote climatization, and notably about their sociopolitical backgrounds, interests and forms of organization? How are their strategies, and the outcomes of their climatizing moves, related to their positionalities within global politics?

Another avenue for future research concerns the outcomes of climatization processes, both in terms of equity and climate justice, and in catalyzing effective climate action. Our findings indicate that such outcomes vary across empirical cases. A positive contribution of climatization to climate governance can therefore not be presupposed. Climatizing moves can be largely symbolic and promote incremental solutions; they often foreground techno-fixes, but may also provide visibility to more transformative strategies of societal change. However, if we take seriously the transversality and complexity of the climate problem, some degree of climatization is almost certainly inevitable for a (more) effective treatment of the problem. Conversely, climatization often ushers new themes and issues into global, national, and subnational climate governance arenas. This may in turn lead to a need to establish new subsidiary or parallel governance processes, and thereby increase the complexity of policymaking and global governance.

As global warming progresses and efforts to mitigate and adapt intensify, living under a changing climate-or in a 'new climate regime' (Latour 2015)-increasingly appears as a central feature of 'our' new, and highly unequal, human condition in the Anthropocene. In other words, we firmly believe that climatization is here to stay. It is thus crucial to better understand this process, recognizing its problems and ambiguities, but also examining its transformative potential and identifying the conditions under which such potentials can be harnessed with a view to building a 
more effective and equitable climate politics. We think that the contributions in this special issue contribute to this endeavour.

Acknowledgements This research is the result of years of discussions initiated thanks to the ClimaCOP project. We thank Amy Dahan, Jean Foyer, and Edouard Morena, as well as all participating colleagues and friends for their friendly critiques and thought-provoking discussions. Earlier versions of this work were presented at EISA 2017 in Barcelona and the Swiss Congress of Political Science in 2021. We are grateful to everyone who commented on the paper on these occasions. We would also like to thank all the contributors to this special issue for their great articles and insightful feedback, as well as the journal's editors. Special thanks to Paul Reeve, whose proofreading not only improved the language but also the content of the article. The research was also funded by the Deutsche Forschungsgemeinschaft (DFG, German Research Foundation) under Germany's Excellence Strategy (EXC 2037 'CLICCS - Climate, Climatic Change, and Society', Project Number: 390683824).

Funding Open Access funding enabled and organized by Projekt DEAL.

\section{Declarations}

Conflict of interest On behalf of all authors, the corresponding author states that there is no conflict of interest.

Open Access This article is licensed under a Creative Commons Attribution 4.0 International License, which permits use, sharing, adaptation, distribution and reproduction in any medium or format, as long as you give appropriate credit to the original author(s) and the source, provide a link to the Creative Commons licence, and indicate if changes were made. The images or other third party material in this article are included in the article's Creative Commons licence, unless indicated otherwise in a credit line to the material. If material is not included in the article's Creative Commons licence and your intended use is not permitted by statutory regulation or exceeds the permitted use, you will need to obtain permission directly from the copyright holder. To view a copy of this licence, visit http://creativecommons.org/licen ses/by/4.0/.

\section{References}

Abbott, K.W. 2018. Orchestration. Strategic Ordering in Polycentric Governance. In Governing Climate Change: Polycentricity in Action?, ed. A. Jordan, D. Huitema, H. Van Asselt, and J. Forster, 188209. Cambridge, UK: Cambridge University Press.

Abbott, K.W., and D. Snidal. 2000. Hard and Soft Law in International Governance. International Organization 54(3): 421-456. https://doi.org/10.1162/002081800551280.

Adler, E., and V. Pouliot. 2011. International Practices. International Theory 3(1): 1-36.

Andonova, L.B. 2010. Public-Private Partnerships for the earth: Politics and Patterns of Hybrid Authority in the Multilateral System. Global Environmental Politics 10(2): 25-53.

Aykut, S.C. 2020. Global by Nature? Three Dynamics in the Making of 'Global Climate Change.' In Globalizing Issues. How Claims, Frames and Problems Cross Borders, ed. E. Neveu and M. Surdez, 277-300. London: Palgrave.

Aykut, S.C., J. Foyer, and E. Morena, eds. 2017. Globalising the Climate: COP21 and the Climatisation of Global Debates. London: Routledge Earthscan.

Bäckstrand, K., and E. Lövbrand. 2006. Planting Trees to Mitigate Climate Change: Contested Discourses of Ecological Modernization, Green Governmentality and Civic Environmentalism. Global Environmental Politics 6(1): 50-75.

Bäckstrand, K., and E. Lövbrand. 2016. The Road to Paris: Contending Climate Governance Discourses in the Post-Copenhagen Era. Journal of Environmental Policy \& Planning 21: 1-19.

Baillat, A. 2018. From Vulnerabilty to Weak Power: Bangladesh in the Fight Against Climate Change. Revue Internationale et Strategique 1: 171-180.

Beck, U. 1986. Risikogesellschaft. Auf dem Weg in eine andere Moderne. Frankfurt am Main: Suhrkamp. 
Bernstein, S., M.M. Betsill, M. Hoffmann, and M. Paterson. 2010. A Tale of Two Copenhagens: Carbon Markets and Climate Governance. Millennium - Journal of International Studies 39(1): 161-173.

Betsill, M.M., and H. Bulkeley. 2004. Transnational Networks and Global Environmental Governance: The Cities for Climate Protection Program. International Studies Quaterly 48(2): 471-493.

Boltanski, L., and E. Chiapello. 1999. Le nouvel esprit du capitalisme. Paris: Gallimard.

Borie, M., M. Mahony, N. Obermeister, and M. Hulme. 2021. Knowing like a global expert organization: Comparative insights from the IPCC and IPBES. Global Environmental Change 68: 102261. https:// doi.org/10.1016/j.gloenvcha.2021.102261.

Campbell, J.L., C. Corson, N.J. Gray, et al. 2014. Studying Global Environmental Meetings to Understand Global Environmental Governance: Collaborative Event Ethnography at the Tenth Conference of the Parties to the Convention on Biological Diversity. Global Environmental Politics 14(3): 1-20.

Dahan, A. 2010. Putting the Earth System in a Numerical Box? The Evolution from Climate Modeling toward Global Change. Studies in the History and Philosophy of Modern Physics 41: 282-292.

Dalby, S. 2016. Political Geography and Climate Change: Introduction to a Virtual Special Issue of Political Geography on Climate Change and Political Geography, November 2015-February 2016. Political Geography 50: 71-73.

Death, C. 2011. Summit Theatre: Exemplary Governmentality and Environmental Diplomacy in Johannesburg and Copenhagen. Environmental Politics 20(1): 1-19.

Edwards, P.N. 2010. A Vast Machine. Computer Models, Climate Data, and the Politics of Global Warming. The MIT Press.

Elbe, S. 2010. Security and Global Health. Cambridge, UK: Polity Press.

Epstein, G.A. 2005. Financialization and the World Economy. Cheltenham, UK: Edward Elgar Publishing.

Floyd, R. 2010. Security and the Environment: Securitisation Theory and US Environmental Security Policy. Cambridge University Press.

Fogel, C. 2004. The Local, the Global and the Kyoto Protocol. In Earthly Politics, Worldly Knowledge. Local and Global in Environmental Governance, ed. M. Long-Martello and S. Jasanoff. Cambridge, MA: MIT Press.

Foyer, J., S.C. Aykut, and E. Morena. 2017. Introduction: COP21 and the "climatisation" of Global Debates. In Globalising the Climate: COP21 and the climatisation of global debates, ed. S.C. Aykut, J. Foyer, and E. Morena, 1-17. London: Routledge Earthscan.

Foyer, J., and Kervran D. Dumoulin. 2017. Objectifying Traditional Knowledge, Re-enchanting the Struggle Against Climate Change. In Globalising the Climate. COP21 and the Climatisation of Global Debates, ed. S.C. Aykut, J. Foyer, and E. Morena, 153-172. London: Routledge.

Geden, O. 2018. Politically Informed Advice for Climate Action. Nature Geoscience 11(6): 380-383.

Graz, J.-C. 2006. Hybrids and Regulation in the Global Political Economy. Competition \& Change 10(2): $230-245$.

Hajer, M. 1995. The Politics of Environmental Discourse: Ecological Modernisation and the Policy Process. Oxford: Clarendon Press.

Hajer, M.A., and P. Pelzer. 2018. 2050-An Energetic Odyssey: Understanding 'Techniques of Futuring' in the Transition Towards Renewable Energy. Energy Research \& Social Science 44: 222-231.

Hale, T. 2016. "All Hands on Deck": The Paris Agreement and Nonstate Climate Action. Global Environmental Politics 16(3): 12-22.

Hall, N. 2015. Money or Mandate? Why International Organizations Engage with the Climate Change Regime. Global Environmental Politics 15(2): 79-97.

Hall, R.B., and T.J. Biersteker. 2002. The Emergence of Private Authority in Global Governance. Cambridge, UK: Cambridge University Press.

Hirschl, R. 2008. The judicialization of politics. In The Oxford Handbook of Political Science, ed. R.E. Goodin, 253-274. Oxford, UK: Oxford University Press.

Huysmans, J. 1998. Security! What do You Mean? From Concept to Thick Signifier. European Journal of International Relations 4(2): 226-255.

Jordan, A., D. Huitema, H. Van Asselt, and J. Forster, eds. 2018. Governing Climate Change: Polycentricity in Action? Cambridge, UK: Cambridge University Press.

Klein, N. 2014. This Changes Everything. Capitalism vs. the Climate. New York: Simon \& Schuster.

Kolleck, N., M. Well, S. Sperzel, and H. Jörgens. 2017. The Power of Social Networks: How the UNFCCC Secretariat Creates Momentum for Climate Education. Global Environmental Politics 17(4): $106-126$. 
Kon Kam King, J., C. Granjou, J. Fournil, and L. Cecillon. 2018. Soil Sciences and the French 4 per 1000 Initiative-The Promises of Underground Carbon. Energy Research \& Social Science 45: 144-152.

Latour, B. 2015. Face à Gaïa: Huit conférences sur le nouveau régime climatique. Paris: La Découverte.

Litfin, K.T. 1999. The Global Gaze: Environmental Remote Sensing, Epistemic Authority, and the Territorial State. In Approaches to Global Governance Theory, ed. M. Hewson and T.J. Sinclair. State University of New York Press.

Littoz-Monnet, A., ed. 2017. The Politics of Expertise in International Organizations: How International Bureaucracies Produce and Mobilize Knowledge. London: Routledge.

Louis, M., and L. Maertens. 2021. Why International Organizations Hate Politics: Depoliticizing the World. Routledge.

Mcdonald, M. 2013. Discourses of climate security. Political Geography 33(1): 42-51.

Methmann, C.P. 2010. 'Climate protection' as Empty Signifier: A Discourse Theoretical Perspective on Climate Mainstreaming in World Politics. Millennium 39(2): 345-372.

Moncel, R., and H. Van Asselt. 2012. All Hands on Deck! Mobilizing Climate Change Action beyond the UNFCCC. Review of European Community \& International Environmental Law 21(3): 163-176.

Neveu, E., and M. Surdez, eds. 2020. Globalizing Issues: How Claims, Frames, and Problems Cross Borders. Basingstoke, Hampshire: Palgrave Macmillan.

Oels, A. 2012. From 'Securitization'of Climate Change to 'Climatization' of the Security Field: Comparing Three Theoretical Perspectives. In Climate Change, Human Security and Violent Conflict. Challenges for Societal Stability, ed. J. Scheffran, M. Brzoska, H.G. Brauch, et al., 185-205. Berlin: Springer.

Paterson, M., and J. Stripple. 2010. My Space: Governing Individual's Carbon Emissions. Environment and Planning D: Society and Space 28(2): 341-362.

Pettenger, M.E., ed. 2007. The Social Construction of Climate Change. Power, Knowledge, Norms and Discourses. Burlington, VT: Ashgate.

Pouliot, V. 2014. Practice Tracing. In Process Tracing: From Metaphor to Analytical Tool, ed. A. Bennett and J.T. Checkel, 237-259. Cambridge, UK: Cambridge University Press.

Ripple, W.J., C. Wolf, T.M. Newsome, et al. 2019. World Scientists' Warning of a Climate Emergency. BioScience. https://doi.org/10.1093/biosci/biz088.

Schüssler, E., C.-C. Rüling, and B.B.F. Wittneben. 2014. Climate Summits: The Limitations of FieldConfiguring Events as Catalysts of Change in Transnational Climate Policy. Academy of Management Journal 57(1): 140-171.

Stritzel, H. 2007. Towards a Theory of Securitization: Copenhagen and Beyond. European Journal of International Relations 13(3): 357-383.

Swyngedouw, E. 2010. Apocalypse Forever? Post-political Populism and the Spectre of Climate Change. Theory, Culture \& Society 27(2/3): 213-232.

Swyngedouw, E., and J. Wilson. 2014. The Post-Political and Its Discontents. Edinburgh University Press.

Trombetta, M.J. 2008. Environmental Security and Climate Change: Analysing the Discourse. Cambridge Review of International Affairs 21(4): 585-602.

Trumbo, C.W. 1996. Constructing Climate Change: Claims and Frames in US News Coverage of an Environmental Issue. Public Understanding of Science 5(3): 269-283.

Van Asselt, H., J. Gupta, and F. Biermann. 2005. Advancing the Climate Agenda: Exploiting Material and Institutional Linkages to Develop a Menu of Policy Options. Review of European Community \& International Environmental Law 14(3): 255-264.

Van Asselt, H., and F. Zelli. 2018. International Governance: Polycentric Governing by and beyond the UNFCCC. In Governing Climate Change. Polycentricity in Action?, ed. A. Jordan, D. Huitema, H.V. Asselt, and J. Forster, 29-46. Cambridge, UK: Cambridge University Press.

Vogler, J. 2016. Climate Change in World Politics. Houndmills, Basingstoke: Palgrave Macmillan.

\section{Special Issue, International Politics (2021) - Table of Content}

Aykut, S.C., E. Morena, and J. Foyer. 2020. 'Incantatory' Governance: Global Climate Politics' Performative Turn and Its Wider Significance for Global Politics. International Politics. https://doi.org/10. 1057/s41311-020-00250-8. 
Dupuits, E. 2020. Reversing Climatisation: Transnational Grassroots Networks and Territorial Security Discourse in a Fragmented Global Climate Governance. International Politics. https://doi.org/10. 1057/s41311-020-00256-2.

de Moor, J. 2020. Alternative Globalities? Climatization Processes and the Climate Movement Beyond COPs. International Politics. https://doi.org/10.1057/s41311-020-00222-y.

Estève, A. 2020. Preparing the French Military to a Warming World: Climatization through Riskification. International Politics. https://doi.org/10.1057/s41311-020-00248-2.

Jayaram, D. 2020. 'Climatizing' Military Strategy? A Case Study of the Indian Armed Forces. International Politics. https://doi.org/10.1057/s41311-020-00247-3.

Maertens, L. 2021. Climatizing the UN Security Council. International Politics. https://doi.org/10.1057/ s41311-021-00281-9.

Méndez, M. 2020. Climate Change from the Streets. How Conflict and Collaboration Strengthen the Environmental Justice Movement. New Haven and London: Yale University Press.

Morena, E. 2020. The Climate Brokers: Philanthropy and the Shaping of a 'US-Compatible' International Climate Regime. International Politics. https://doi.org/10.1057/s41311-020-00249-1.

Publisher's Note Springer Nature remains neutral with regard to jurisdictional claims in published maps and institutional affiliations. 